\title{
ムライトの焼結及び微構造に及ぼす $\mathrm{Y}_{2} \mathrm{O}_{3}$ 添加の影響（第 1 報） \\ 一相変化亡焼結性——
}

\author{
黄 啓样・方 徳揚 \\ 国立成功大学材料工程学系, 中華民国台㴒省台南市大学路一號
}

\author{
Effects of $\mathrm{Y}_{2} \mathrm{O}_{3}$ Addition on the Sinterability and Microstructure of Mullite (Part 1) \\ —Phase Transformation and Sinterability- \\ Chii-Shyang HWANG and Der-Yang FANG \\ Department of Materials Engineering, National Cheng-Kung University, Tainan, Taiwan, R.O.C.
}

[Received March 2, 1992; Accepted May 21, 1992]

The effect of addition of $\mathrm{Y}_{2} \mathrm{O}_{3}$ on the sinterability and microstructure of mullite was studied by differential thermal analysis, X-ray powder diffraction,scanning and transmission electron microscopy, and dilatometry. The mullite powder compacts containing 2-10 wt\% $\mathrm{Y}_{2} \mathrm{O}_{3}$ were sintered at $1500^{\circ} \mathrm{C}$ in air. The solid state reaction of $\mathrm{Y}_{2} \mathrm{O}_{3}$ and mullite during the sintering process produced some crystalline phases of yittrium silicates and $\alpha-\mathrm{Al}_{2} \mathrm{O}_{3}$. The product phases were dependent on the amount of $\mathrm{Y}_{2} \mathrm{O}_{3}$ addition. The yittrium silicate and $\mathrm{Al}_{2} \mathrm{O}_{3}$ melted into a liquid phase at higher sintering temperature, which enhanced the sinterability of mullite powders. During the furnace cooling process, the liquid phase crystallized, and different crystalline phases were obtained depending on the amount of $\mathrm{Y}_{2} \mathrm{O}_{3}$.

Key-words : $\mathrm{Y}_{2} \mathrm{O}_{3}$, Mullite, Liquid phase sintering, Microstructure, Crystallization

\section{1. 緒 言}

ムライトは $\mathrm{Al}_{2} \mathrm{O}_{3}-\mathrm{SiO}_{2} 2$ 成分系における常圧下で安定 な唯一の化合物であり, アルミナより優れた高温強度, 耐 クリープ性を持っているので1), 高温構造用材料として注 目され，また比較的低い誘電率などの特性も持っている2).

ムライトは焼結しにくい酸化物で, 金属アルコキシドの加 水分解やゾル-ゲル法で作製した高純度ムライト粉末を用 いて緻密な焼成体を作るには $1650^{\circ} \mathrm{C}$ 以上の高温で $2 \sim 4$ 時 間の保持が必要である3) 7). そのため添加物によりムラ イトの焼結を促進する研究が多数行われている ${ }^{8)}$.

$\mathrm{Y}_{2} \mathrm{O}_{3}$ をムライト又は $\mathrm{Al}_{2} \mathrm{O}_{3}-\mathrm{SiO}_{2} 2$ 成分系に添加すると ムライトの焼結温度を著しく下げ，柱状粒子とすること9), この棒状のムライト粒子は高温での焼成体の勒性を改善で

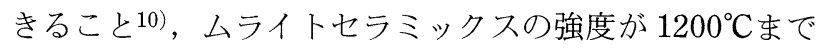
低下しないこと(1),12)などが報告されている. また $\mathrm{Y}_{2} \mathrm{O}_{3}$ は $\mathrm{Si}_{3} \mathrm{~N}_{4}$ の焼結及び高温での機械的性質の改善にも優れた効 果を持つことが知られている13) 15). $\mathrm{Si}_{3} \mathrm{~N}_{4}$ 焼結体の模擬 粒界相としての $\mathrm{Y}_{2} \mathrm{O}_{3}-\mathrm{Al}_{2} \mathrm{O}_{3}-\mathrm{SiO}_{2}$ ガラスの特性も報告さ れている16),17).

本研究はムライトセラミックスの焼結性を改善すること を目的として， $\mathrm{Y}_{2} \mathrm{O}_{3}$ を添加したムライト混合粉末を作製
し, 加熱時の結晶相変化, 焼結性, 微構造などについて検 討したものである.

\section{2. 実 験}

\section{1 試料の調製と成形}

実験に用いたムライトは $\mathrm{Al}_{2} \mathrm{O}_{3} / \mathrm{SiO}_{2}$ モル比1.51の純度 $99.85 \%$, 平均粒径 $1.46 \mu \mathrm{m}$ の粉末（秩父セメント製, $\mathrm{MP}-20$ ) であり, $\mathrm{Y}_{2} \mathrm{O}_{3}$ は純度 $99.9 \%$, 平均粒径 $15 \mu \mathrm{m}$ の 粉末 (和光純薬工業) である.この $\mathrm{Y}_{2} \mathrm{O}_{3}$ 粉末はまずアル ミナポットミルで粉砕し, 沈降法で $1 \mu \mathrm{m}$ 以下の粉末を採 取し, 添加粉末とした. 所定量のムライト粉末と $\mathrm{Y}_{2} \mathrm{O}_{3}$ 粉 末を秤量し, アルミナポットミル中で, エタノールを用い $12 \mathrm{~h}$ 湿式混合した後, $90^{\circ} \mathrm{C}$ 温浴上でかくはんしながら 蒸発乾固させ, 約 $110^{\circ} \mathrm{C}$ 乾燥器中で, 一昼夜乾燥して混 合粉末とした. 混合粉末はべークライト内張の金型を用い て, $5 \times 5 \times 45 \mathrm{~mm}$ の棒状試験片に $25 \mathrm{MPa}$ で予備成形し た後, $98 \mathrm{MPa}$ で静水圧成形を行った。

\section{2 焼成}

混合粉末の相変化温度を調べるため, Setaram製, TAG-24型示差熱分析 (DTA) により， $6^{\circ} \mathrm{C} / \mathrm{min}$ の昇温 速度で $1500^{\circ} \mathrm{C}$ な゙加熱した. 試験片の焼成は炭化ケイ素 質発熱体電気炉を用いて, $6^{\circ} \mathrm{C} / \mathrm{min}$ で昇温し $1500^{\circ} \mathrm{C} て ゙ ~ 2 \mathrm{~h}$ 保持して炉冷した。一部の粉末又は試験片は Pt はくに入 れ, 所定温度まで加熱した後, 炬外に取り出し空気中急冷 した．炉冷試料及び急冷試料について，それぞれ結晶相の 検討及び微構造観察を行った.

\section{3 測定及び観察}

結晶相の同定は粉末 X 線回折法 (XRD) により行った. 測定には理学電機製, D/MAXIIIを用い, $\mathrm{Cu} \mathrm{K} \alpha$ 線, 印加 電圧 $30 \mathrm{kV}$, 管電流 $20 \mathrm{~mA}$, 走査速度 $4 \% / \mathrm{min}$ の条件で 行った。棒状試験片の加熱収縮の測定は Setaram 製, DHT $2050 \mathrm{KN}$ 型示差熱膨張計で $6^{\circ} \mathrm{C} / \mathrm{min}$ の昇温速度で 行った. 成形体の生かさ密度は体積と重量から算出し, 焼 成体のかさ密度は水を用いて, アルキメデス法により求め た. 焼成体の微構造は走査型電子顕微鏡 (SEM; HITACHI, S-2500型）及び透過型電子顕微鏡（TEM; JOEL, 400-EX) を用いて観察した. 以下 $\mathrm{Y}_{2} \mathrm{O}_{3}$ 添加試料 
は $\mathrm{MYX}$ の記号で略記するが，ここで $X$ は添加 $\mathrm{Y}_{2} \mathrm{O}_{3}$ 量

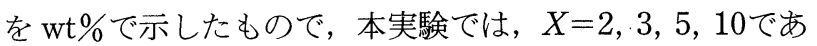
る。

\section{3. 結果と考察}

\section{1 粉末の DTA 曲線}

図 1 は 2 10 $\mathrm{wt} \% \mathrm{Y}_{2} \mathrm{O}_{3}$ を添加した混合粉末の DTA 曲 線を示す. MY5 と MY10試料は $1310^{\circ} \sim 1390^{\circ} \mathrm{C}$ の間に一 つの吸熱ピークがあった. MY2 と MY3 試料もこの温度 範囲にやや吸熱の現象 (矢印処) が認められるが, MY10 試料のみは $1390^{\circ} \sim 1420^{\circ} \mathrm{C}$ の間に比較的シャープなもう一 つの吸熱ピークがあった。これらの結果により， $\mathrm{Y}_{2} \mathrm{O}_{3}$ の 添加量によって試料の昇温過程での反応が異なることが分 かった。

\section{2 焼成過程の結晶相変化}

各温度で急冷した MY5 とMY10試料の粉末 X 線回折パ タンを図 2 に示す。図の結果により, 両試料の昇温過程で の反応及び結晶相変化をまとめると，つぎのようになる：

$$
\begin{aligned}
& 2 \mathrm{Y}_{2} \mathrm{O}_{3}+3 \mathrm{Al}_{2} \mathrm{O}_{3} \cdot 2 \mathrm{SiO}_{2} \stackrel{\sim}{\sim} 1300^{\circ} \mathrm{C} \\
& 2 \mathrm{Y}_{2} \mathrm{SiO}_{5}\left(X_{1}\right)+3 \mathrm{Al}_{2} \mathrm{O}_{3} \\
& 2 \mathrm{Y}_{2} \mathrm{SiO}_{5}\left(X_{1}\right)+3 \mathrm{Al}_{2} \mathrm{O}_{3} \cdot 2 \mathrm{SiO}_{2} \stackrel{1300^{\circ} \sim 1390^{\circ} \mathrm{C}}{\longrightarrow} \\
& \quad 2 \mathrm{Y}_{2} \mathrm{Si}_{2} \mathrm{O}_{7}(\alpha)+3 \mathrm{Al}_{2} \mathrm{O}_{3} \\
& \mathrm{Y}_{2} \mathrm{Si}_{2} \mathrm{O}_{7}(\alpha) \stackrel{1385^{\circ} \sim 1405^{\circ} \mathrm{C}}{\longrightarrow} \mathrm{Y}_{2} \mathrm{Si}_{2} \mathrm{O}_{7}(\beta) \\
& \mathrm{Y}_{2} \mathrm{Si}_{2} \mathrm{O}_{7}(\alpha \text { 又は } \beta)+\mathrm{Al}_{2} \mathrm{O}_{3} \\
& \quad+\left(3 \mathrm{Al}_{2} \mathrm{O}_{3} \cdot 2 \mathrm{SiO}_{2}\right) \longrightarrow \text { Liquid }
\end{aligned}
$$

すなわち，これらの試料は $1200^{\circ} \mathrm{C} に お い て ， \mathrm{Y}_{2} \mathrm{O}_{3}$ とムラ イトを反応して， $\mathrm{Y}_{2} \mathrm{SiO}_{5}\left(X_{1}\right)$ 及び $\alpha-\mathrm{Al}_{2} \mathrm{O}_{3}$ を生成し， $1300^{\circ} \sim 1390^{\circ} \mathrm{C}$ 間で $\mathrm{Y}_{2} \mathrm{SiO}_{5}\left(X_{1}\right)$ とムライトとの反応と ともに， $\alpha-\mathrm{Y}_{2} \mathrm{Si}_{2} \mathrm{O}_{7}$ と $\alpha-\mathrm{Al}_{2} \mathrm{O}_{3}$ を生成する. $\mathrm{MY} 10$ 試料で は更に $1385^{\circ} \sim 1405^{\circ} \mathrm{C}$ の間で $\alpha-\mathrm{Y}_{2} \mathrm{Si}_{2} \mathrm{O}_{7}$ が $\beta-\mathrm{Y}_{2} \mathrm{Si}_{2} \mathrm{O}_{7}$ に相 転移した。 MY5 試料は更に高い温度においても $\beta$ -

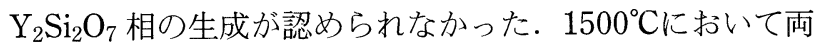
試料とも $\mathrm{Y}_{2} \mathrm{Si}_{2} \mathrm{O}_{7}$ 相が認められなくなり，ムライトと少量 $\alpha-\mathrm{Al}_{2} \mathrm{O}_{3}$ のみが認められた。 以上の結果から $\mathrm{Y}_{2} \mathrm{O}_{3}$ 添加量 の異なる試料では, 異なる反応が起こることが分かった.

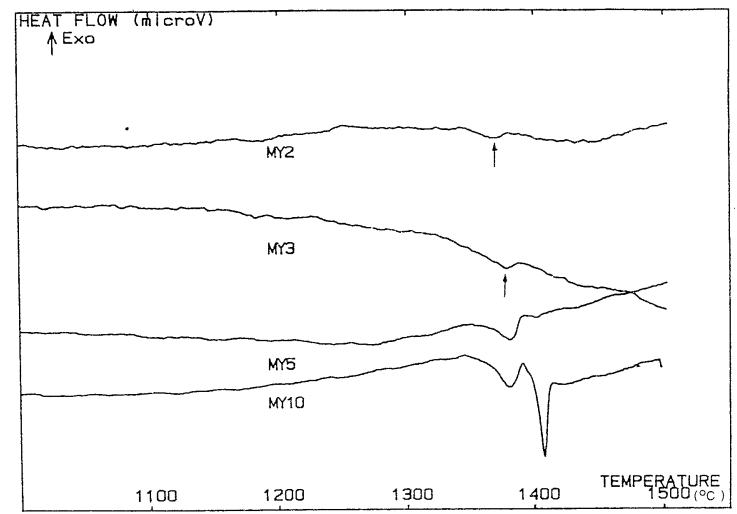

Fig. 1. DTA curves of the samples with various amount of $\mathrm{Y}_{2} \mathrm{O}_{3}$ addition.
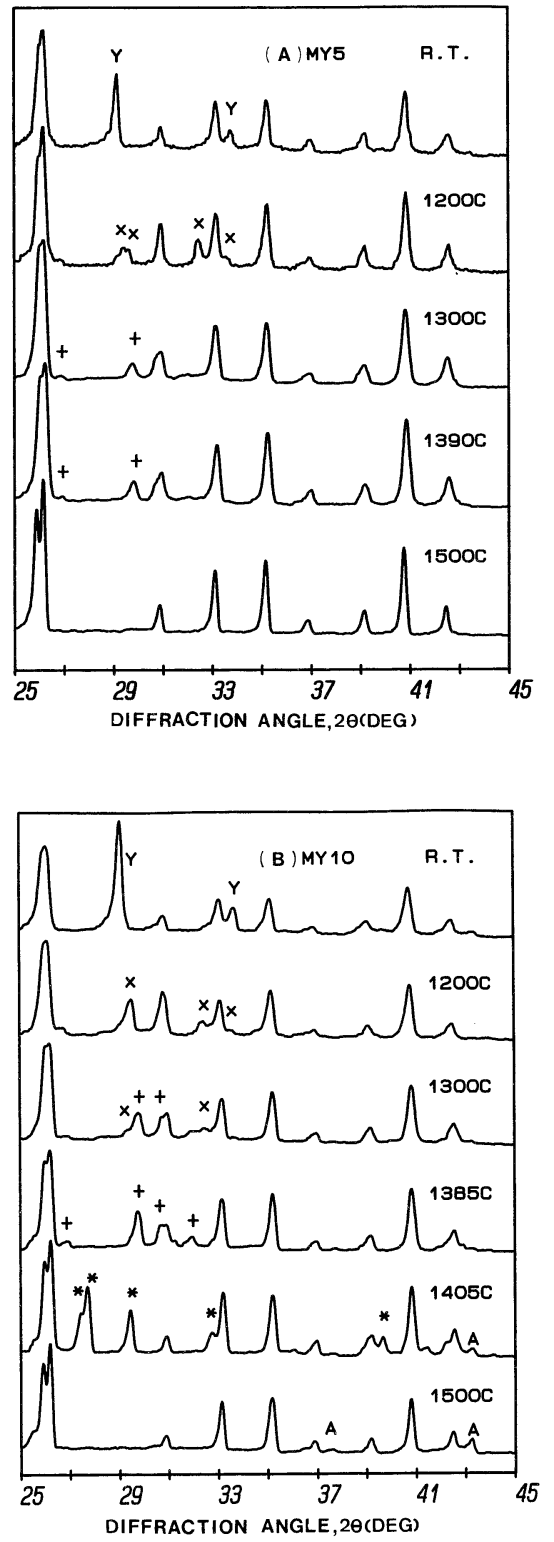

Fig. 2. XRD patterns of the samples quenched at various temperatures. (A) $5 \mathrm{wt} \% \mathrm{Y}_{2} \mathrm{O}_{3}$, (B) $10 \mathrm{wt} \% \mathrm{Y}_{2} \mathrm{O}_{3}$ addition. $\mathrm{Y}$ : $\mathrm{Y}_{2} \mathrm{O}_{3}, \mathrm{X}: \mathrm{Y}_{2} \mathrm{SiO}_{5}\left(X_{1}\right), \mathrm{A}: \alpha-\mathrm{Al}_{2} \mathrm{O}_{3},+: \alpha-\mathrm{Y}_{2} \mathrm{Si}_{2} \mathrm{O}_{7}, *: \beta-\mathrm{Y}_{2} \mathrm{Si}_{2} \mathrm{O}_{7}$, unmarked : mullite.

これは図 1 の結果とも対応でき，図 1 の $1310^{\circ} \sim 1390^{\circ} \mathrm{C}$ の 間の吸収熱ピークは $X_{1}-\mathrm{Y}_{2} \mathrm{SiO}_{5}$ と $\alpha-\mathrm{Al}_{2} \mathrm{O}_{3}$ の生成によるも の，1390 $\sim 1420^{\circ} \mathrm{C}$ の間の吸収熱ピークは $\alpha-\mathrm{Y}_{2} \mathrm{Si}_{2} \mathrm{O}_{7}$ から $\beta-\mathrm{Y}_{2} \mathrm{Si}_{2} \mathrm{O}_{7}$ への相転移によるものである.

Ito らは $\mathrm{Y}_{2} \mathrm{Si}_{2} \mathrm{O}_{7}$ の多形間の転移温度を以下のように報 告した ${ }^{18)}$.

$$
\alpha \stackrel{1225^{\circ} \mathrm{C}}{\longrightarrow} \beta \stackrel{1445^{\circ} \mathrm{C}}{\longrightarrow} \gamma \stackrel{1535^{\circ} \mathrm{C}}{\longrightarrow} \delta
$$

本実験での $\beta-\mathrm{Y}_{2} \mathrm{Si}_{2} \mathrm{O}_{7}$ の生成温度は Ito らの報告した温度 と若干差異があるが, $\mathrm{Y}_{2} \mathrm{O}_{3}$ 添加量の増加は高温型相, $\beta$ $\mathrm{Y}_{2} \mathrm{Si}_{2} \mathrm{O}_{7}$ の生成に役立つと考えられる. 一方，(1) と (2)の 反応式ではかなりの量の $\alpha-\mathrm{Al}_{2} \mathrm{O}_{3}$ が生成するはずである が，それが図 2 の XRD 結果ではほとんど認められなかっ た.この点について以下のように説明できると思われる. 
(a) $\mathrm{Y}$ を含有する化合物の $\mathrm{X}$ 線回折パターンの強度は, ムライトと $\mathrm{Al}_{2} \mathrm{O}_{3}$ より強いので, $\mathrm{Al}_{2} \mathrm{O}_{3}$ の $\mathrm{X}$ 線回折パター ンが全般的に比較的小さくなると感じられる. (b) $\mathrm{Y}_{2} \mathrm{O}_{3}$ 添加量の最も多いMY10試料の場合には，(1)の反応式に より, $100 \mathrm{~g}$ の混合粉末 $\left(10 \mathrm{~g}\right.$ 又は 0.044 モルの $\mathrm{Y}_{2} \mathrm{O}_{3}$ を 含有する）を用いると， $6.77 \mathrm{~g}$ (0.066モル) の $\mathrm{Al}_{2} \mathrm{O}_{3}$ を 生成するはずである。しかし， $1300^{\circ} \mathrm{C}$ 以下では核生成， 成長してきた $\mathrm{Al}_{2} \mathrm{O}_{3}$ 粒子の粒径が小さくて，その結晶性 が悪いので, $\mathrm{Al}_{2} \mathrm{O}_{3}$ の $\mathrm{X}$ 線回折パターンが認められにく くなった. $1300^{\circ} \mathrm{C}$ 以上の温度では,(2)の反応式により, 0.066 乇ルの $\mathrm{Al}_{2} \mathrm{O}_{3}$ を生成するはずである. しかし, $\mathrm{Al}_{2} \mathrm{O}_{3}-$ $\mathrm{SiO}_{2}-\mathrm{Y}_{2} \mathrm{O}_{3} 3$ 成分の共融温度は約 $1350^{\circ} \mathrm{C}$ であり19), これ 以上の温度には一部の $\mathrm{Al}_{2} \mathrm{O}_{3}$ は $\mathrm{Y}_{2} \mathrm{Si}_{2} \mathrm{O}_{7}$ と共融して液相 になるので, 認められる $\mathrm{Al}_{2} \mathrm{O}_{3}$ の $\mathrm{X}$ 線回折パターン $\left(2 \theta=43.4^{\circ}\right)$ が小さいと考えられる. $5 \mathrm{wt} \% \mathrm{Y}_{2} \mathrm{O}_{3}$ を添加 する MY5 試料の場合には, 生成した $\mathrm{Al}_{2} \mathrm{O}_{3}$ の量が比較的 少なく，また $\mathrm{Y}_{2} \mathrm{Si}_{2} \mathrm{O}_{7}$ と反応して液相になるので, $\mathrm{Al}_{2} \mathrm{O}_{3}$ の $\mathrm{X}$ 線回折パターンがほとんど認められなかったと思わ れる.

図 3 は $1500^{\circ} \mathrm{C} て ゙ ~ 2 h$ 焼成後, 炉冷した各試料の $\mathrm{X}$ 線回 折図である. 炉冷試料にはムライトのほかに生成した結晶 相が認められる.この結晶相は $\mathrm{Y}_{2} \mathrm{O}_{3}$ 添加量によって異な り, MY5 試料では $\alpha-\mathrm{Y}_{2} \mathrm{Si}_{2} \mathrm{O}_{7}$ と微量の $\alpha-\mathrm{Al}_{2} \mathrm{O}_{3}, \mathrm{MY} 10$ 試 料では $\alpha-\mathrm{Y}_{2} \mathrm{Si}_{2} \mathrm{O}_{7}$ と少量の $\alpha-\mathrm{Al}_{2} \mathrm{O}_{3}$ が認められた. 一方, MY2 と MY3 試料にはムライト以外の結晶相は検出でき なかった. 図 2 の急冷試料の結果と図 3 の炉冷した試料 の結果を比べると, $1500^{\circ} \mathrm{C}$ からの冷却過程においても $\mathrm{Y}_{2} \mathrm{O}_{3}$ 添加量の違いによって異なる反応が起こることが分 かった。すなわち, MY5 とMY10の試料では, 液相より $\alpha$ 又は $\beta$ 相の $\mathrm{Y}_{2} \mathrm{Si}_{2} \mathrm{O}_{7}$ 及び $\alpha-\mathrm{Al}_{2} \mathrm{O}_{3}$ を析出（(4) 式の逆反 応）したが，MY2 と MY3 試料では液相はそのまま固化 しガラス相として残留した.これらの結果から焼成過程で 生成した液相は, 冷却過程において結晶化するが, 結晶化

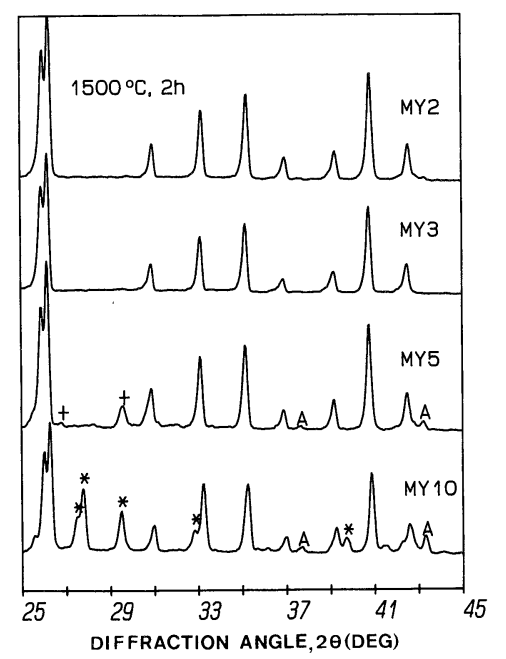

Fig. 3. XRD patterns of the samples with various amount of $\mathrm{Y}_{2} \mathrm{O}_{3}$ addition fired at $1500^{\circ} \mathrm{C}$ for $2 \mathrm{~h}$ and cooling in furnance. A : $\alpha-\mathrm{Al}_{2} \mathrm{O}_{3},+: \alpha-\mathrm{Y}_{2} \mathrm{Si}_{2} \mathrm{O}_{7}, *: \beta-\mathrm{Y}_{2} \mathrm{Si}_{2} \mathrm{O}_{7}$, unmarked : mullite.
速度は $\mathrm{Y}_{2} \mathrm{O}_{3}$ 添加量の多くなるほど速くなると認められ る.

\section{3 昇温収縮曲線と焼成体かさ密度}

ムライトの緻密化に対する $\mathrm{Y}_{2} \mathrm{O}_{3}$ 添加量の影響を検討す

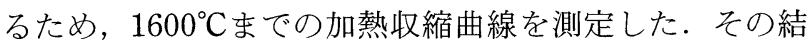
果を図 4 に示す。収縮開始温度は無添加の試料では, $1400^{\circ} \mathrm{C}$ 付近であるが, $\mathrm{Y}_{2} \mathrm{O}_{3}$ を添加した試料では著しく低 温度側に移行して，1200〜 $1300^{\circ} \mathrm{C}$ となる．焼成収縮開始 後の収縮速度は無添加試料では小さく, $1600^{\circ} \mathrm{C} て ゙ の$ 収縮 量も $5 \%$ であった。これに対して $\mathrm{Y}_{2} \mathrm{O}_{3}$ を添加した試料の 収縮速度は $\mathrm{Y}_{2} \mathrm{O}_{3}$ 添加量の増加とともに大きくなり，5， $10 \mathrm{wt} \%$ 添加のものでは $1450^{\circ} \mathrm{C} て ゙$ 収縮量が $18 \%$ となった. すなわち， $\mathrm{Y}_{2} \mathrm{O}_{3}$ の添加によりムライトの焼結が著しく促 進されることが分かった。

$\mathrm{Al}_{2} \mathrm{O}_{3}-\mathrm{SiO}_{2}-\mathrm{Y}_{2} \mathrm{O}_{3} 3$ 成分系の共融点は約 $\left.1350^{\circ} \mathrm{C} 19\right)$ で, このムライトの焼結が促進されるのは焼成過程で液相が生 成することによるものと考えられる．しかし，(1)～(4) 式よりこの液相は $\mathrm{Al}_{2} \mathrm{O}_{3}, \mathrm{SiO}_{2}, \mathrm{Y}_{2} \mathrm{O}_{3} 3$ 成分が同時に反応 する 3 成分共融ではなく, 主として $\mathrm{Y}_{2} \mathrm{Si}_{2} \mathrm{O}_{7}$ と $\mathrm{Al}_{2} \mathrm{O}_{3}$ の 反応によって生成するものと思われる.

なお，MY10試料の収縮曲線は他のものに比べると $1200^{\circ} \sim 1310^{\circ} \mathrm{C}$ の間で比較的大きい収縮，及び $1380^{\circ} \sim$ $1410^{\circ} \mathrm{C}$ の間に顕著な膨張が認められた．前者の収縮現象

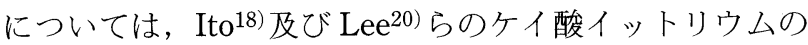
各結晶相の格子定数, 相変化に伴う体積变化についての報 告及び前節の結果から，以下のような固相反応が起こるこ とによる体積収縮と考えられる。

$$
\begin{aligned}
& 2 \mathrm{Y}_{2} \mathrm{O}_{3}+3 \mathrm{Al}_{2} \mathrm{O}_{3} \cdot 2 \mathrm{SiO}_{2} \\
& \quad \longrightarrow 2 \mathrm{Y}_{2} \mathrm{SiO}_{5}\left(X_{1}\right)+3 \mathrm{Al}_{2} \mathrm{O}_{3} \quad \Delta V=-12.5 \%
\end{aligned}
$$

しかしこの反応の温度が低く，焼成体の密度がまた低いの で，収縮現象があまり顕著には現れなかったものと思われ る. 一方, 後者の顕著な膨張現象について, $\alpha-\mathrm{Y}_{2} \mathrm{Si}_{2} \mathrm{O}_{7}$ か ら $\beta-\mathrm{Y}_{2} \mathrm{Si}_{2} \mathrm{O}_{7}$ への相転移により，6\%体積膨張することに よる結果と考えられる.

MYX 炉冷焼成体の理論密度は上記の結晶相の分析結果 により, 以下のように推算した.

(a) 各 $\mathrm{MYX}$ 試料中に $\mathrm{Y}_{2} \mathrm{O}_{3}$ とムライトと反応して生 成したものは：

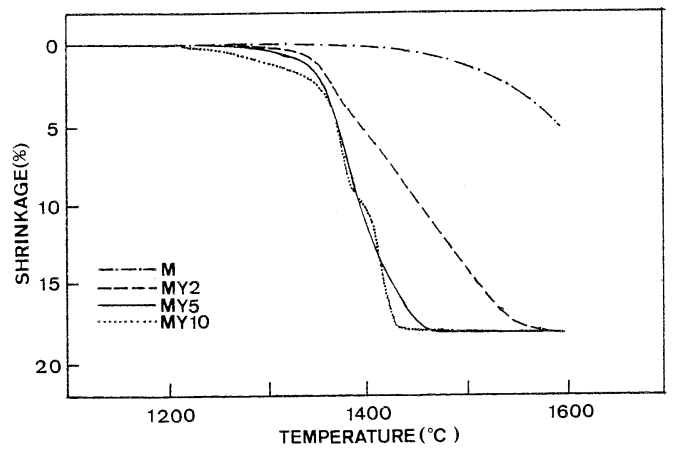

Fig. 4. Shrinkage curves of the green samples with various amount of $\mathrm{Y}_{2} \mathrm{O}_{3}$ addition. 
Table 1. Theoretical density, bulk density, and relative density of sintered body.

\begin{tabular}{cccc} 
specimens & $\begin{array}{c}\text { Theoretical } \\
\text { density }\left(\mathrm{g} / \mathrm{cm}^{3}\right)\end{array}$ & $\begin{array}{c}\text { Bulk density } \\
\left(\mathrm{g} / \mathrm{cm}^{3}\right)\end{array}$ & $\begin{array}{c}\text { Relative } \\
\text { density (\%) }\end{array}$ \\
\hline $1700^{\circ} \mathrm{C}, 1 \mathrm{~h}$ (MYO) & 3.17 & 3.13 & 98.74 \\
$1500^{\circ} \mathrm{C}, 2 \mathrm{~h}$ (MY2) & 3.20 & 3.16 & 98.75 \\
$1500^{\circ} \mathrm{C}, 2 \mathrm{~h}$ (MY3) & 3.22 & 3.15 & 97.83 \\
$1500^{\circ} \mathrm{C}, 2 \mathrm{~h}$ (MY5) & 3.28 & 3.18 & 97.00 \\
$1500^{\circ} \mathrm{C}, 2 \mathrm{~h}$ (MY10) & 3.37 & 3.24 & 96.14 \\
\hline
\end{tabular}

$$
\begin{aligned}
\text { MY10 }: & \mathrm{Y}_{2} \mathrm{O}_{3}+3 \mathrm{Al}_{2} \mathrm{O}_{3} \cdot 2 \mathrm{SiO}_{2} \\
& \longrightarrow \beta-\mathrm{Y}_{2} \mathrm{Si}_{2} \mathrm{O}_{7}+3 \mathrm{Al}_{2} \mathrm{O}_{3} \\
\text { MY5 }: & \mathrm{Y}_{2} \mathrm{O}_{3}+3 \mathrm{Al}_{2} \mathrm{O}_{3} \cdot 2 \mathrm{SiO}_{2} \\
& \longrightarrow \alpha-\mathrm{Y}_{2} \mathrm{Si}_{2} \mathrm{O}_{7}+3 \mathrm{Al}_{2} \mathrm{O}_{3}
\end{aligned}
$$

MY2, MY3 : $\mathrm{Y}_{2} \mathrm{O}_{3}+3 \mathrm{Al}_{2} \mathrm{O}_{3} \cdot 2 \mathrm{SiO}_{2} \longrightarrow$ glass

(b) 各生成相の理論密度 $\left(\mathrm{g} / \mathrm{cm}^{3}\right)$ :

$$
\begin{array}{rr}
3 \mathrm{Al}_{2} \mathrm{O}_{3} \cdot 2 \mathrm{SiO}_{2}: 3.17 & \alpha-\mathrm{Y}_{2} \mathrm{Si}_{2} \mathrm{O}_{7}: 4.30 \\
\alpha-\mathrm{Al}_{2} \mathrm{O}_{3}: 3.99 & \beta-\mathrm{Y}_{2} \mathrm{Si}_{2} \mathrm{O}_{7}: 4.03 \\
\mathrm{Y}_{2} \mathrm{O}_{3}: 5.03 & \text { glass }: 3.77^{*}
\end{array}
$$

（a）と（b）に基づき計算した焼成体の理論密度，測定した かさ密度と相対密度を表 1 に示す。表 1 から燒成体の相 対密度が $\mathrm{Y}_{2} \mathrm{O}_{3}$ 添加量の増加とともにやや減少し, MY2 試料の $98.7 \%$ から MY10試料の $96.1 \%$ に変化することが分 かる. $1500^{\circ} \mathrm{C}, 2 \mathrm{~h}$ 焼成した MY2 試料の相対密度が $1700^{\circ} \mathrm{C}, 1 \mathrm{~h}$ 焼成した無添加のものと同じ程度であること はムライトの暁結に対する $\mathrm{Y}_{2} \mathrm{O}_{3}$ 添加の効果を示すもので ある。

\section{4 微構造観察}

図 5 は $1500^{\circ} \mathrm{C}, 2 \mathrm{~h}$ 炉冷焼成体の研磨面の写真である. 焼成体中の気孔径と気孔量は $\mathrm{Y}_{2} \mathrm{O}_{3}$ 添加量とともにやや増 加する傾向が認められる．MY2 試料には $1 \mu \mathrm{m}$ 以下の気 孔が均一に分散するが，MY10試料では $3 \sim 5 \mu \mathrm{m}$ の気孔 が存在している. 全般的にみると, $\mathrm{Y}_{2} \mathrm{O}_{3}$ の添加量が例え ば 2 又は $3 \mathrm{wt} \%$ と少ない場合にも，均一な組織をもつ焼 成体が得られた：したがって，焼成体中に生成した液相は ムライト粒子に対する濡れ性が相当良いと考光られる．図 6 は各焼成条件で得られた MY10試料の研磨面の写真で ある. 昇温中の $1450^{\circ} \sim 1500^{\circ} \mathrm{C}$ 間の焼成体では気孔が小

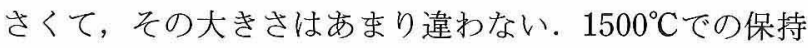
過程では保持時間が長くなると気孔が大きくなり, 気孔の 数が減少した.この現象は液相中に存在する小さい気孔が 次第に集合し，大きくなることによるものと考えられる. 更にこのような大きい気孔の生成に伴って体積が若千膨張 するので, 焼成体の相対密度が表 1 に示すように若干低 下したものと思われる。

$1500^{\circ} \mathrm{C}, 2 \mathrm{~h}$ 焼成し炉冷した MY2, MY5, MY10試料の

\footnotetext{
*ガラスの理論密度は表 2 に示す MY2 焼成体中のガラス組成 により，作製したガラスをアルキメデス法により求めたもの である。
}

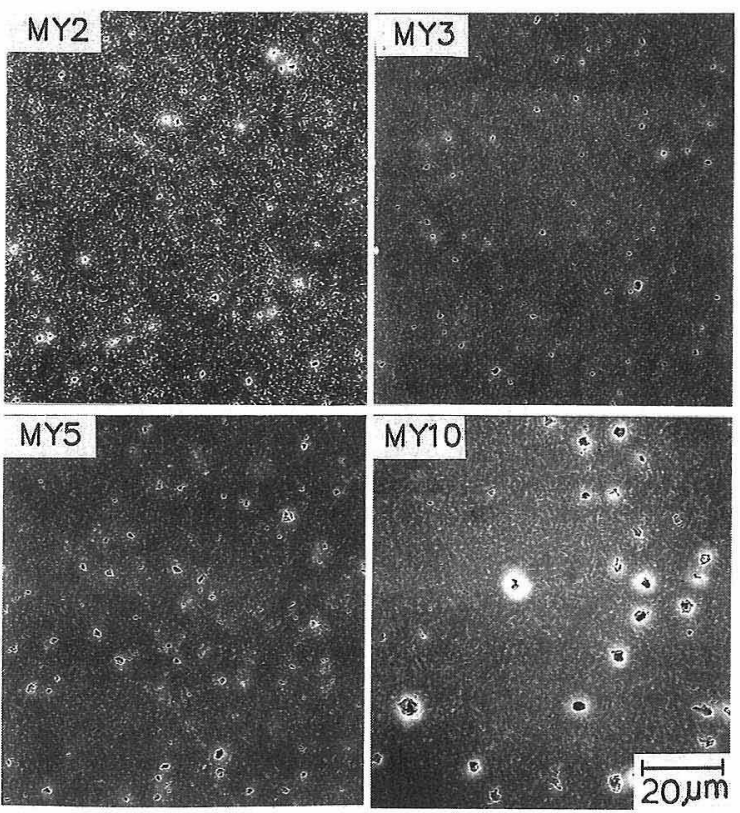

Fig. 5. SEM photographs of the samples with various amount of $\mathrm{Y}_{2} \mathrm{O}_{3}$ addition sintered at $1500^{\circ} \mathrm{C}$ for $2 \mathrm{~h}$.
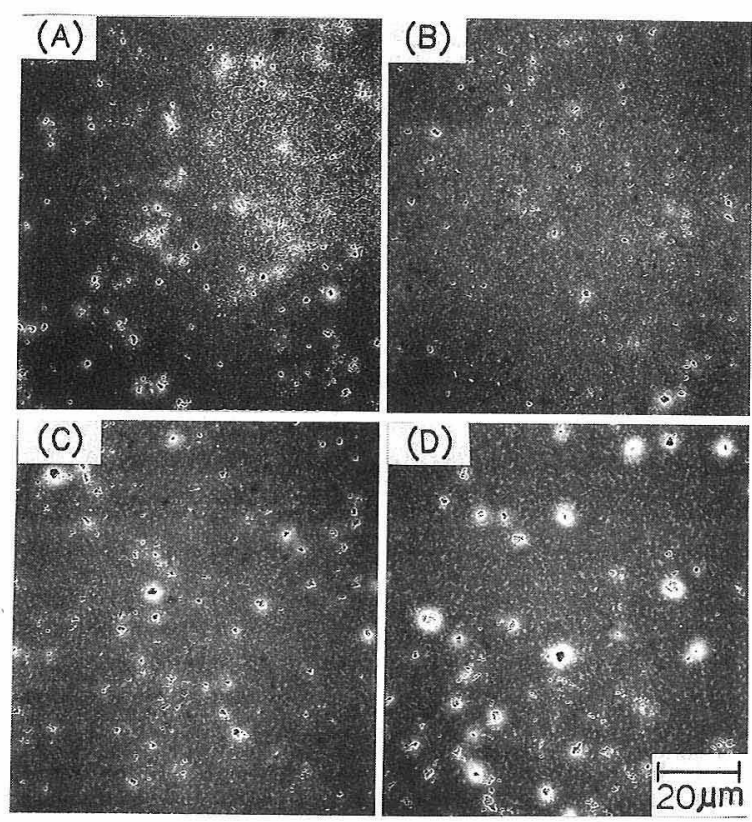

Fig. 6. SEM photographs of the $10 \mathrm{wt} \% \mathrm{Y}_{2} \mathrm{O}_{3}$-mullite sample sintered at (A) $1450{ }^{\circ} \mathrm{C}, 3 \mathrm{~min},(B) 1475^{\circ} \mathrm{C}, 3 \mathrm{~min}$, (C) $1500^{\circ} \mathrm{C}, 3$ $\min ,(\mathrm{D}) 1500^{\circ} \mathrm{C}, 1 \mathrm{~h}$.

TEM 写真をそれぞれ図 7，8，9 に示す．TEMを用い て $\mathrm{Y}_{2} \mathrm{O}_{3}$ 添加量の少ない $\mathrm{MY} 2$ 試料の暗視野像を観察する 過程では, ムライト粒子間の粒界層の明るさは試料の傾き 角度によらず，ほぼ同じ暗灭色なので, 粒界相はアモルファ スであると認められた。 なお，回折パターンをとるとき， 電子ビームの直径が約 $0.5 \mu \mathrm{m}$ であるので, アモルファス の薄い粒界相だけでなく，その周り及びその下の結晶相に も当たったので，それに対応したスポット（図7(B)）も 認められた．MY5 試料の粒界層はアモルファス又は $\alpha$ - $\mathrm{Y}_{2}$ $\mathrm{Si}_{2} \mathrm{O}_{7}$ 結晶相であり, 添加量の多い MY10試料の粒界層は 

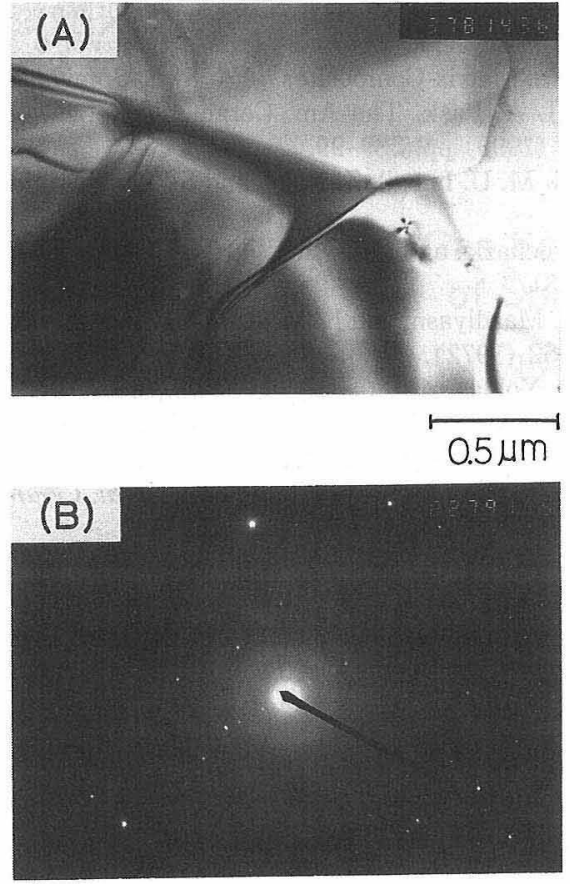

Fig. 7. TEM microanalysis of $2 \mathrm{wt} \% \mathrm{Y}_{2} \mathrm{O}_{3}$-mullite sample sintered at $1500^{\circ} \mathrm{C}$ for $2 \mathrm{~h}$ and cooling in furnance. (A) bright field image, (B) electron diffraction pattern.

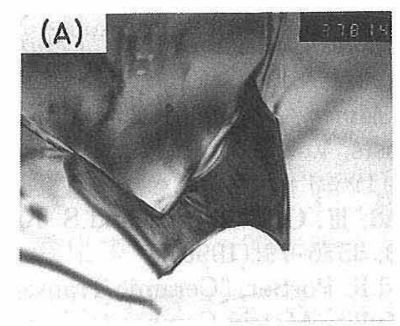

(C)

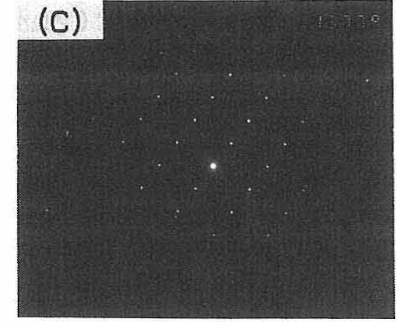

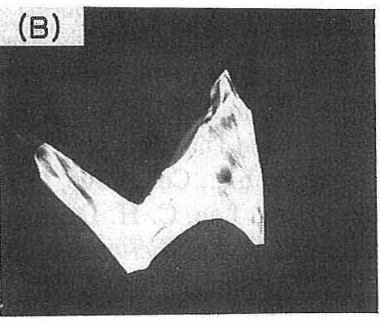

$\stackrel{\longmapsto .5 \mu \mathrm{m}}{\longmapsto}$

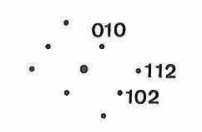

[201] zone axis

$\alpha-Y_{2} \mathrm{Si}_{2} \mathrm{O}_{\text {, }}$
Fig. 8. TEM microanalysis of $5 \mathrm{wt} \% \mathrm{Y}_{2} \mathrm{O}_{3}$-mullite sample sintered at $1500^{\circ} \mathrm{C}$ for $2 \mathrm{~h}$ and cooling in furnance. (A) bright field image, (B) dark field image, (C) electron diffraction pattern showing $\alpha-\mathrm{Y}_{2} \mathrm{Si}_{2} \mathrm{O}_{7}$ phase.

$\mathrm{Y}_{2} \mathrm{Si}_{2} \mathrm{O}_{7}$ 結晶相（大部分は $\beta$ 型であるが， $\alpha$ 型の $\mathrm{Y}_{2} \mathrm{Si}_{2} \mathrm{O}_{7}$ も少量認められる) であり，ほとんどアモルファスのない ことが分かった．これらの結果は 3.2 節のX 線回折結果 とよく対応する。すなわち，同じ焼成，炉冷過程である が， $\mathrm{Y}_{2} \mathrm{O}_{3}$ 添加量の少ない焼成体ではムライト粒子間のア モルファス粒界相がそのまま炉冷過程に残留, 固化した が， $\mathrm{Y}_{2} \mathrm{O}_{3}$ 添加量の多い場合にはそのアモルファス粒界相 が結晶化した。これは $\mathrm{Y}_{2} \mathrm{O}_{3}$ 添加量の多い試料では焼成過 程に生成した $\mathrm{Y}_{2} \mathrm{O}_{3}-\mathrm{Al}_{2} \mathrm{O}_{3}-\mathrm{SiO}_{2} 3$ 成分系ガラスに含有し た $\mathrm{Y}_{2} \mathrm{O}_{3}$ の量が多くなるほど炉冷中に結晶化しやすくなる

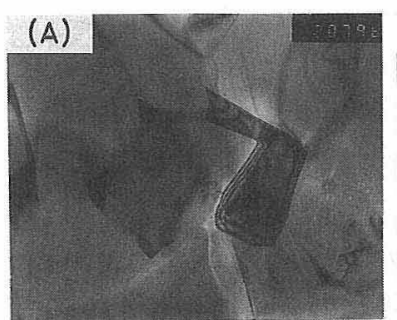

(C)

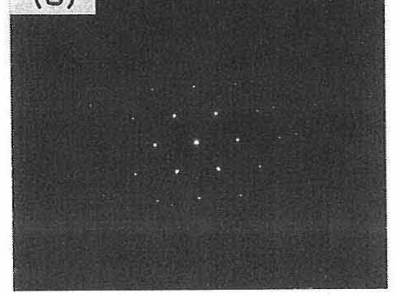

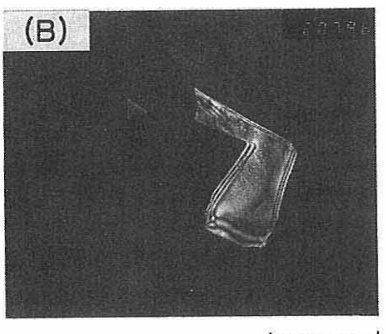

$1 \mu \mathrm{m}$

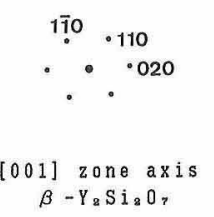

Fig. 9. TEM microanalysis of $10 \mathrm{wt} \% \mathrm{Y}_{2} \mathrm{O}_{3}$-mullite sample sintered at $1500^{\circ} \mathrm{C}$ for $2 \mathrm{~h}$ and cooling in furnance. (A) bright field image, (B) dark field image, (C) electron diffraction pattern showing $\beta-\mathrm{Y}_{2} \mathrm{Si}_{2} \mathrm{O}_{7}$ phase.

\section{ものと思われる.}

村上は9 $\mathrm{Y}_{2} \mathrm{O}_{3}-\mathrm{Al}_{2} \mathrm{O}_{3}-\mathrm{SiO}_{2} 3$ 成分系ガラスについてガラ スの組成が共融点の組成に近いほど，活性化エネルギーが 高くなり，結晶化しにくくなると指摘している．本実験で の $1500^{\circ} \mathrm{C}, 2 \mathrm{~h}$ 焼成, 急冷した MY2 MY10焼成体中の ガラス組成を EDSにより成分分析して, 酸化物組成に換 算した結果を表 2 に示す。両試料中のガラスの分析值はそ れぞれ 2 個所でとった值の平均であるが， 2 個所にはほぼ 同じ值が得られた. したがって, 得られた分析值は相対值 として定性的に比較することができると考えられる. 両試 料中の $\mathrm{Al}_{2} \mathrm{O}_{3}$ 含有量はほぼ同じであるが, $\mathrm{MY} 2$ 試料の $\mathrm{SiO}_{2} / \mathrm{Y}_{2} \mathrm{O}_{3}$ の比は $\mathrm{MY} 10$ 試料のものより高い. $\mathrm{MY} 2$ のガ ラス組成は $\mathrm{MY} 10$ のもより $\mathrm{Y}_{2} \mathrm{O}_{3}-\mathrm{Al}_{2} \mathrm{O}_{3}-\mathrm{SiO}_{2} 3$ 成分系 の共融点の組成に近い。これらの結果は村上の報告々一致 している，したがって，炉冷したMY2 とMY3 試料中に MY5 とMY10試料と異なり, ガラス相が存在するのは, そのガラス相の活性化エネルギーが比較的高いことによる ものと考えられる.

一方, Michel21) 23) らの報告により, 液相焼結のムライ トはその $\mathrm{Al}_{2} \mathrm{O}_{3}$ の含有固溶量が $3 \mathrm{Al}_{2} \mathrm{O}_{3} \cdot 2 \mathrm{SiO}_{2}$ (sinteredmullite) と $2 \mathrm{Al}_{2} \mathrm{O}_{3} \cdot \mathrm{SiO}_{2}$ (fused-mullite) の間にある. 本 実験では出発原料のムライトは $3 \mathrm{Al}_{2} \mathrm{O}_{3} \cdot 2 \mathrm{SiO}_{2}$ に近い組成 を持つので, 液相焼結過程においてムライトに固溶する $\mathrm{Al}_{2} \mathrm{O}_{3}$ 量の増加とともにムライトから液相中に溶入する $\mathrm{SiO}_{2}$ (free silica) が増加する可能性がある. それにより

Table 2. Compositions of glass existing in MY2 and MY10 specimens sintered at $1500^{\circ} \mathrm{C}$ for $2 \mathrm{~h}$ and quenched out of furnance (wt \%).

\begin{tabular}{rrrr}
\hline Specimens & $\mathrm{Al}_{2} \mathrm{O}_{3}$ & $\mathrm{SiO}_{2}$ & $\mathrm{Y}_{203}$ \\
\hline MY2 & 20.67 & 43.14 & 36.19 \\
MY10 & 20.29 & 38.75 & 40.96
\end{tabular}


$\mathrm{Y}_{2} \mathrm{O}_{3}$ 添加量の少ない試料，例えば $2 \mathrm{wt} \%$ 添加のものには その液相中の $\mathrm{SiO}_{2}$ 含有量が相対的に増加し, $\mathrm{Y}_{2} \mathrm{O}_{3}-\mathrm{Al}_{2} \mathrm{O}_{3}$ $\mathrm{SiO}_{2} 3$ 成分系の共融点の組成に, より近い組成をもつと も考えられる．なお，液相の結晶化は化学組成だけでな く，その存在状態ももう一つの要因である.MY2 と MY3 試料には, 生成した液相が少ないので, MY5 と MY10の試料より，その粒界相の液相の量が比較的少な く，粒界層の厚さが比較的薄いので，結晶化しにくくなる ものとも考えられる．この炉冷過程における液相の結晶化 挙動については，第 2 報で報告する予定である.

\section{4. 結 論}

(1) $\mathrm{Y}_{2} \mathrm{O}_{3}$ をムライトに添加すると著しく焼結を促進 し， $1500^{\circ} \mathrm{C}$ 焼成温度で緻密な焼 結体が得られた。

(2) $\mathrm{Y}_{2} \mathrm{O}_{3}$ は焼成中にムライトと反応して，まず $X_{1}-\mathrm{Y}_{2} \mathrm{SiO}_{5}$ 及び $\alpha-\mathrm{Al}_{2} \mathrm{O}_{3}$ を生成するが， $X_{1}-\mathrm{Y}_{2} \mathrm{SiO}_{5}$ は更に ムライトと反応し $\alpha$ 又は $\beta$ の $\mathrm{Y}_{2} \mathrm{Si}_{2} \mathrm{O}_{7}$ 相 と $\alpha-\mathrm{Al}_{2} \mathrm{O}_{3}$ を生 成する. $\mathrm{Y}_{2} \mathrm{Si}_{2} \mathrm{O}_{7}$ と $\alpha-\mathrm{Al}_{2} \mathrm{O}_{3}$ はより高温で溶融して液相に なった。

（3）焼成過程で生成した液相は冷却過程において結晶 化するが，その結晶化速度は $\mathrm{Y}_{2} \mathrm{O}_{3}$ 添加量の多くなるほど 速くなる．結晶化により生成する相も $\mathrm{Y}_{2} \mathrm{O}_{3}$ 添加量により 異なり， $5,10 \mathrm{wt} \% \mathrm{Y}_{2} \mathrm{O}_{3}$ 添加試料には，主としてそれぞ れ $\alpha$ と $\beta$ の $\mathrm{Y}_{2} \mathrm{Si}_{2} \mathrm{O}_{7}$ が結 晶化する。

（本文の一部は1992年 1 月第 30回セラミックス基礎討論会にて発 表したものである)

謝辞 本研究は中華民國行政院國家科學委員會研究費の援 助（NSC 80-0405-E006-14）を受けて行ったものである。 また 論文をまとめるに当たり神奈川大学・濱野健也教授のご助言を頂 いた.ここに記して感謝の意を表します。

$$
\text { 文献 }
$$

1) P. A. Lessing, R. S. Gordon and K. S. Mazdiyasni, J. Am. Ceram. Soc., 58, 149-50 (1975).
2) S. Kanzaki, M. Ohashi, H. Tabata, T. Kurihara, S. Iwai and S. Wakabayashi, "Ceramics Transaction, Vol. 6, Mullite and Mullite Matrix Composites”, Ed. by S. Sōmiya, R. F. Davis and J. A. Pask, The Am. Ceram. Soc., Inc., Westerville, Ohio (1990) pp. 389-99.

3) M. G. M. U. Ismail, Z. Nakai and S. Sōmiya, ibid., pp. 23141.

4) S. Prochazka and F. J. Klug, J. Am. Ceram. Soc., 66, 874-80 (1983).

5) K. S. Mazdiyasni and L. M. Brown, J. Am. Ceram. Soc., 55, 548-52 (1972)

6) B. E. Yoldas, Am. Ceram. Soc. Bull., 59, 479-83 (1980).

7) S. Kanzaki, H. Tabata, T. Kumazawa and S. Ohta, J. Am. Ceram. Soc., 68, C6-7 (1985).

8) Y. M. Agamawi and J. White, Trans. Brit. Ceram. Soc., 61, 293-323 (1962).

9）村上勇一郎, 山本博一, Seramikkusu Ronbunshi (J. Ceram. Soc. Japan), 99, 215-21 (1991).

10）森 利之, 小杉直樹, 石川芳光, 窪田吉孝, Seramikkusu Ronbunshi (J. Ceram. Soc. Japan), 98, 1307-12 (1990).

11) N. Ushifusa and S. Ogihara, J. Ceram. Soc. Japan, Inter. Ed., 97, 678-84 (1989).

12）三田村 孝，小林秀彦，石橋 昇，秋葉徳二，Seramikkusu Ronbunshi (J. Ceram. Soc. Japan), 99, 351-56 (1991).

13) W. E. Lee and G. E. Hilmas, J. Am. Ceram. Soc., 72, 193137 (1989).

14) M. K. Cinibulk and G. Thomas, J. Am. Ceram. Soc., 73, 1606-12 (1990)

15) J. C. Almeida, A. T. Fonseca, R. N. Correia and J. L. Baptista, Mater. Sci. and Engineer., A 109, 395-400 (1989).

16）小田耕平, 吉尾哲夫, Seramikkusu Ronbunshi (J. Ceram. Soc. Japan), 97, 1493-97 (1989).

17）小田耕平, 吉尾哲夫, Seramikkusu Ronbunshi (J. Ceram. Soc. Japan), 99, 1150-52 (1991).

18) J. Ito and H. Johnson, Am. Miner., 53, 1940-52 (1968).

19) "Phase Diagram for Ceramists, Vol. II", The Am. Ceram. Soc., Inc., Columbus, Ohio (1969) p. 165.

20) W. E. Lee, C. H. Drummond, III, G. E. Hilmas and S. Kumar, J. Am. Ceram. Soc., 73, 3575-79 (1990).

21) D. Michel, L. Mazerolles and R. Portier, "Ceramic Transactions, Vol. 6, Mullite and Mullite Matrix Composites", Ed. by S. Sōmiya, R. F. Davis and J. A. Pask, The Am. Ceram. Soc., Inc., Westerville, Ohio (1990) pp. 435-47.

22) H. Schneider, ibid., pp. 135-57.

23) J. A. Pask, Ceramics Int'l, 9, 107-13 (1983). 